\title{
Direct speciation analysis of thallium based on solid phase extraction and specific retention of a TI(III) complex on alumina coated with sodium dodecyl sulfate
}

\author{
Ewa Biaduń $^{1} \cdot$ Monika Sadowska $^{1}$. Natalia Ospina-Alvarez ${ }^{1}$. \\ Beata Krasnodębska-Ostręga ${ }^{1}$
}

Received: 3 June 2015 / Accepted: 19 August 2015 / Published online: 29 August 2015

(C) The Author(s) 2015. This article is published with open access at Springerlink.com

\begin{abstract}
Alumina $\left(\mathrm{Al}_{2} \mathrm{O}_{3}\right)$ with an average particle size of $63 \mu \mathrm{m}$ was modified with the anionic surfactant sodium dodecyl sulfate (SDS) and then applied to (i) solid phase extraction and separation of both thallium(I) and thallium(III), and (ii) preconcentration of $\mathrm{Tl}(\mathrm{III})$ from waste water samples. Only $\mathrm{Tl}(\mathrm{III})$, in the form of its complex with diethylenetriaminepentaacetate (DTPA), was retained on the sorbent, from where it can be eluted with $40 \%$ nitric acid. Thallium species were then quantified by ICP MS. The method was characterized by a LOD of $25 \mathrm{pg}$ of Tl(I) and $160 \mathrm{pg}$ of Tl(III) in $10 \mathrm{~mL}$ samples. A large excesses of Tl(I) over Tl(III) was tolerated, and relatively high levels of other metal ions, such as a 500-fold excess of $\mathrm{Pb}$ (II) and $\mathrm{Cd}(\mathrm{II})$, and a 2000-fold excess of $\mathrm{Zn}(\mathrm{II})$, respectively, do not interfere. The sorbent was easily prepared and possesses a high loading capacity, and these properties make it an attractive material for rapid and efficient extraction and speciation of $\mathrm{Tl}$.
\end{abstract}

Keywords Thallium(III) Alumina $\cdot$ SDS $\cdot$ Solid phase extraction $\cdot$ ICP MS $\cdot$ Direct speciation analysis

\section{Introduction}

Thallium occurs in the environment at a low level of concentration; however, it is toxic even in trace amounts. The dominant species of $\mathrm{Tl}$ is a free cation of $\mathrm{Tl}(\mathrm{I})$, but also noticeable amounts of Tl(III) were found in water (21-26 $\left.\mathrm{ng} \mathrm{L}^{-1}\right)$ [1],

Beata Krasnodębska-Ostręga

bekras@chem.uw.edu.pl

1 Faculty of Chemistry, University of Warsaw, Pasteura 1, 02-093, Warsaw, Poland suspended particular matter of water $\left(349 \mu \mathrm{g} \mathrm{L}^{-1}\right)$ [2] and plants $\left(110-230 \mu \mathrm{g} \mathrm{kg}^{-1}\right)$ [3]. In organic form it was detected as dimethylthallium in the Atlantic Ocean (up to $3 \mathrm{ng} \mathrm{L}^{-1}$ ) [4]. All forms of $\mathrm{Tl}$ present in the environment have different toxicity. The toxicity of $\mathrm{Tl}(\mathrm{III})$ species highly depends on the chemical form. Therefore, speciation analysis of $\mathrm{Tl}$ is especially important. Thallium can easily penetrate into the body and replace potassium. Monovalent Tl also interacts with sulfur and sulfur contained in enzymes, which causes their deactivation. Thallium(III) is more toxic than $\mathrm{Tl}(\mathrm{I}), \mathrm{Cu}(\mathrm{II})$ and $\mathrm{Cd}(\mathrm{II})$, and similar to $\mathrm{Hg}(\mathrm{II})$ [5], as it causes creation of reactive oxygen species [6]. The solubility of Tl(I) compounds, except chlorides, is relatively high, and they can be transported by water to vast areas. Thallium can be accumulated in plant tissues and enter the food chain. Elevated levels of $\mathrm{Tl}$ in water pollute soil and plants and pose a threat to human health. Mobility of $\mathrm{Tl}$ in soil is a very important factor influencing the scale of toxic effects caused by this element [7]. $\mathrm{Tl}(\mathrm{I})$ is more stable in aqueous solutions while $\mathrm{Tl}(\mathrm{III})$ is more reactive and hydrolyses in neutral and alkaline solutions. Thallium(III) is less stable and can be electrochemically reduced to $\mathrm{Tl}(\mathrm{I})$ very fast $\left(\log \mathrm{K} \cong 40, \mathrm{E}_{\text {red }}\left(\mathrm{Tl}^{3+/} \mathrm{Tl}^{+}\right)=+1.26 \mathrm{~V}\right)$. The reduction is faster than complexation of $\mathrm{Tl}(\mathrm{III})$ (usually $\log \mathrm{K}=3 \div 9$ ). At $\mathrm{pH}<7$ the hydrolysis of $\mathrm{Tl}(\mathrm{III})$ can be observed. In higher $\mathrm{pH}$ hydroxide complexes are formed. Reduction of Tl(III) to Tl(I) can be limited by complexation of $\mathrm{Tl}$ by reagents such as chlorides $(\operatorname{logK}=17)$ [8], oxalates $(\log \mathrm{K}=16)$ [9], EDTA $(\log \mathrm{K}=37)$ or DTPA $(\log \mathrm{K}=46)[10]$. The rate of reduction of Tl(III) in the presence of chlorides is up to $40 \%$, in the presence of acetates up to $80 \%$ and in the presence of DTPA only $1-3 \%$ of Tl(III) was reduced to Tl(I) [11]. However, the chelates of $\mathrm{Tl}(\mathrm{III})$ are not stable in the presence of plant matrix, and their reduction is accelerated by UV radiation. The stability constants of Tl(I) complexes with both inorganic and organic ligands are very low [12]. 
Chromatographic separation hyphenated with elemental detection is the most common method applied in speciation analysis. After conservation of the sample Tl(I) exists as a cation and $\mathrm{Tl}(\mathrm{III})$ as a large anion ([Tl(III)DTPA $]^{2-}$ or $\mathrm{Tl}(\mathrm{III}) \mathrm{Cl}_{4}{ }^{-}$). Therefore, in the separation process cation exchange, anion exchange, and size exclusion mechanisms can be applied $[8,10,13]$. The separation can be carried out in the normal and reversed phase mode $[10,14]$. The ratio between the content of $\mathrm{Tl}(\mathrm{I})$ and $\mathrm{Tl}(\mathrm{III})$ is a very important parameter determining the choice of chromatographic column.

The content of Tl(III) in environmental samples is at minor or even trace levels. It is difficult to determine without errors, particularly when the sample matrix is complex. Therefore, a possibility of separation and preconcentration of trivalent $\mathrm{Tl}$ is a crucial part of $\mathrm{Tl}$ speciation analysis. The extraction of $\mathrm{Tl}$ from water or extracts and absorption on a solid sorbent can be a good solution. In the case of Tl(III) the advantages of solid phase extraction are: separation of $\mathrm{Tl}(\mathrm{III})$ from dominating $\mathrm{Tl}(\mathrm{I})$ and interfering compounds, and preconcentration of $\mathrm{Tl}(\mathrm{III})$. SPE allows achieving $\mathrm{Tl}$ concentration above the determination limit. Moreover, the absorbed analyte can be stored for a long time. SPE is characterized by a high rate of recovery and it can be coupled with a various methods of determination, such as inductively coupled plasma mass spectrometry (ICP MS) [15], UV-Vis spectrophotometry [16] or atomic absorption spectrometry [17]. The differences in chemical properties of various forms of $\mathrm{Tl}$ are the basis of their separation and preconcentration from environmental samples. Trace amounts of $\mathrm{Tl}$ have been pre-concentrated on modified multi-layer carbon nanotubes [18]. Application of the positively charged nitrocellulose allows retaining $\mathrm{Tl}(\mathrm{III}) \mathrm{Cl}_{4}^{-}$. The content of $\mathrm{Tl}(\mathrm{I})$ was determined indirectly [17]. $\mathrm{Tl}$ was also preconcentrated from environmental samples on alumina modified with oxine. In the presence of EDTA only $\mathrm{Tl}(\mathrm{I})$ was retained. The total content was determined after reduction of Tl(III) [19]. Another sorbent applied for the analysis of water samples containing $\mathrm{Tl}(\mathrm{III})$ is silica gel with octadecyl-groups (SGX C18) chemically modified with DDTC. It forms complexes with both $\mathrm{Tl}(\mathrm{I})$ and Tl(III), but only Tl(III)DDTC is retained on the column. Before the analysis the samples were preserved - Tl(III) was converted into a complex Tl(III)DTPA [15]. SGX C18 was also used as a sorbent for complexes of $\mathrm{TlCl}_{4}{ }^{-}$formed in water after addition of large amount of chlorides [20]. The chloride complex of Tl(III) was as well retained on the nano-alumina. Total content was determined after oxidation of $\mathrm{Tl}(\mathrm{I})$ to $\mathrm{Tl}(\mathrm{III})$ (indirect speciation) [16].

The aim of this study was to develop a simple analytical procedure of sample pretreatment - separation of Tl(I) from Tl(III)DTPA and preconcentration of Tl(III) from high sample volumes. Expected high enrichment should enable to determine traces of Tl(III) using elemental methods like anodic stripping voltammetry (ASV) and ICP MS. The study was based on the difference in retention of both $\mathrm{Tl}$ forms on alumina modified with an anionic surfactant - sodium dodecyl sulfate (SDS). The method was applied for quantitative determination of Tl(III) in wastewater collected in an industrial region of Southern Poland. Trace amounts of $\mathrm{Tl}(\mathrm{III})$ in this sample were already detected, and reported in our previous study [2].

\section{Experimental}

\section{Chemicals}

Sodium dodecyl sulfate (SDS) ReagentPlus $\geq 98.5 \%$ (Sigma Aldrich, www.sigmaaldrich.com), $\mathrm{Al}_{2} \mathrm{O}_{3}$ (activity stage I) for column chromatography, particle size $0.063-0.200 \mathrm{~mm}$ (70230 mesh ASTM) (Merck, www.merckgroup.com), acetone analytical grade (Chempur, www.chempur.pl), acetonitrile (ACN) gradient grade for liquid chromatography (Merck, www.merckgroup.com), ethanol $96 \%\left(\mathrm{~d}=0.808 \mathrm{~g} \mathrm{~L}^{-1}\right)$ pure pro analysis (POCh, www.poch.com.pl), $\mathrm{HNO}_{3} 68 \%$ $\left(\mathrm{d}=1.42 \mathrm{~g} \mathrm{~mL}^{-1}\right.$ ) ultranal (Cheman, www.ciechtrading. com), $\mathrm{CH}_{3} \mathrm{COONa} \cdot 3 \mathrm{H}_{2} \mathrm{O}\left(\mathrm{M}=136.08 \mathrm{~g} \mathrm{~mol}^{-1}\right)$ pure pro analysis (Chempur, www.chempur.pl), $\mathrm{CH}_{3} \mathrm{COOH}$ $96 \%\left(\mathrm{~d}=1.06 \mathrm{~g} \mathrm{~mL}^{-1}\right)$ Suprapur (Merck, www. merckgroup.com), diethylenetriaminepentaacetic acid (DTPA, M $=393.35 \mathrm{~g} \mathrm{~mol}^{-1}$ ) puriss pro analysis (Sigma Aldrich, www.sigmaaldrich.com), NaOH $30 \%$ ( $\mathrm{d}=1.33 \mathrm{~g} \mathrm{~mL}^{-1}$ ) Suprapur (Merck, www.merckgroup.com), $\mathrm{Tl}\left(\mathrm{NO}_{3}\right)_{3} \cdot 3 \mathrm{H}_{2} \mathrm{O}\left(444.44 \mathrm{~g} \mathrm{~mol}^{-1}\right)$ purum (Sigma Aldrich, www.sigmaaldrich.com). Standard solution of $\mathrm{TlNO}_{3}$ containing $1 \mathrm{mg} \mathrm{L}^{-1} \mathrm{Tl}\left(\mathrm{d}=1.02 \mathrm{~g} \mathrm{~mL}^{-1}\right)$ was obtained from Merck. All solutions were prepared using deionized water from Milli-Q-Water-System (Merck Millipore, USA, www. merckmillipore.com). The solution containing $0.15 \mathrm{~mol} \mathrm{~L}^{-1}$ DTPA was prepared by dissolving $5.9 \mathrm{~g}$ DTPA with $0.7 \mathrm{~mL} 30 \% \mathrm{NaOH}$ in water and diluting it to $100 \mathrm{~mL}$. The $0.2 \mathrm{~mol} \mathrm{~L}^{-1}$ (pH 5.5) acetate buffer was prepared by dissolving $2.72 \mathrm{~g} \mathrm{CH}_{3} \mathrm{COONa} \cdot 3 \mathrm{H}_{2} \mathrm{O}$ and $220 \mu \mathrm{L} 96 \%$ $\mathrm{CH}_{3} \mathrm{COOH}$ in water, and diluting it to $100 \mathrm{~mL}$. The standard solution of $\mathrm{Tl}(\mathrm{III})$ containing ca. $18 \mathrm{mg} \mathrm{L}^{-1}$ was prepared when needed by dissolving ca. $4 \mathrm{mg}$ of $\mathrm{Tl}\left(\mathrm{NO}_{3}\right)_{3} \cdot 3 \mathrm{H}_{2} \mathrm{O}$ (one crystal) in $100 \mathrm{~mL}$ of solution containing $0.025 \mathrm{~mol} \mathrm{~L}^{-1}$ DTPA and $0.1 \mathrm{~mol} \mathrm{~L}^{-1}$ acetate buffer (pH 5.5). Thallium(III) in water samples was stabilized by adding $1 \mathrm{~mL}$ of the $0.15 \mathrm{~mol} \mathrm{~L}^{-1}$ solution of DTPA to $5 \mathrm{~mL}$ of the water sample.

\section{SPE procedure}

The sorbent was prepared by mixing $500 \mathrm{~g}$ of alumina and $17 \mathrm{~mL}$ of solution containing $34 \mathrm{mg}$ SDS [19]. Then the solution was stirred with magnetic stirrer for $10 \mathrm{~min}$. The supernatant was decanted and the SDS-coated alumina was rinsed thoroughly with several portions of water. The wet sorbent was placed into a syringe $(\varphi 13 \mathrm{~mm})$ with a filter, packed using 
the vacuum pump, and covered with a second filter. To improve the homogeneity of the sorbent, it was loaded on the columns while still wet and then it was slowly dried.

Separation of the two forms of thallium $[\mathrm{Tl}(\mathrm{I})$ and Tl(III)DTPA] was performed using an Agilent SampliQ 12-Position Solid Phase Extraction chamber (Agilent, USA, www.agilent.com) connected with a vacuum pump (KNF Neuberger, Germany, www.knf.com) and handmade columns filled with modified alumina as a sorbent.

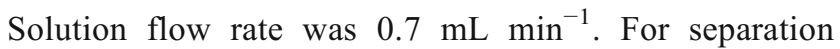
and preconcentration of $\mathrm{Tl}(\mathrm{III})$ the following sequence of solutions was applied to the SPE column: (1) $2.0 \mathrm{~mL}$ of $0.1 \mathrm{~mol} \mathrm{~L}^{-1} \mathrm{HNO}_{3}$, (2) $1.0 \mathrm{~mL} \mathrm{H} \mathrm{H}_{2} \mathrm{O}$, (3) $1-100 \mathrm{~mL}$ of sample, (3A) $3 \mathrm{~mL}$ of water (4) $3.0 \mathrm{~mL}$ of $40 \%$ nitric acid. Steps 1 and 2 were applied to clean the column and to activate the active sites of the sorbent. Tl(I) is supposed to leave the column in step 3, while Tl(III)DTPA is retained in step 3 and then eluted in step 4 . The scheme of the procedure is featured in Table 1.

\section{Instrumentation}

For spectrometric determination NEXION 300D mass spectrometer (Perkin Elmer, USA, www.perkinelmer.com) with Meihard-type nebulizer and Scott-type spray chamber was applied. ICP MS determinations were performed with the following parameters: sweeps: 40, replicates: 5 , dwell time: $50 \mathrm{~ms}$, ICP RF power: $1600 \mathrm{~W}$, deflector voltage: $-9 \mathrm{~V}$, nebulizer gas flow: $1 \mathrm{~L} \mathrm{~min}^{-1}$, plasma gas flow: $18 \mathrm{~L} \mathrm{~min}^{-1}$, auxiliary gas flow: $1.2 \mathrm{~L} \mathrm{~min}^{-1}$ and monitored isotopes: ${ }^{203} \mathrm{Tl}$ and ${ }^{205} \mathrm{Tl}$. Quantitative analysis program was used to automatically correct the intensities of interfering isobaric and molecular ions. For quantitative determinations the calibration curve method was applied.

The results obtained using ICP MS were compared with the results obtained using stripping voltammetry (ASV). The measurements were done using $\mu$ AUTOLAB TYPE II (ECOCHEMIE, BV, The Netherlands, www.metrohmautolab.com) with three electrodes: working electrode hanging mercury drop electrode (HMDE), reference

Table 1 The SPE procedure for separation of Tl(I) from Tl(III) and preconcentration of Tl(III)

\begin{tabular}{|c|c|c|}
\hline Step & Reagent & Aim \\
\hline 1 & $\begin{array}{l}2.0 \mathrm{~mL}^{0.1} \mathrm{~mol} \mathrm{dm}^{-3} \\
\mathrm{HNO}_{3}\end{array}$ & Cleaning \& Conditioning \\
\hline 2 & $1.0 \mathrm{~mL} \mathrm{H}{ }_{2} \mathrm{O}$ & $\mathrm{pH}$ increasing \\
\hline 3 & $5-100 \mathrm{~mL}$ of sample & $\begin{array}{l}\text { Sample introduction } \\
\text { [retention of Tl(III) and leaching of } \mathrm{Tl}(\mathrm{I})]\end{array}$ \\
\hline $3 \mathrm{~A}$ & $3 \mathrm{~mL} \mathrm{H}_{2} \mathrm{O}$ & Additional elution of co-retained $\mathrm{Tl}(\mathrm{I})$ \\
\hline 4 & $3 \mathrm{~mL} \mathrm{HNO}_{3}$ & Elution of Tl(III) \\
\hline
\end{tabular}

electrode $-\mathrm{Ag} / \mathrm{AgCl}\left(3 \mathrm{~mol} \mathrm{~L}{ }^{-1} \mathrm{KCl}\right)$, auxiliary electrode Pt wire. All measurements were performed in the range of potentials from -0.8 to $0.25 \mathrm{~V}$. Tl signal was recorded at a potential $-0.528 \mathrm{~V}$. Preconcentration was carried out for 300 $1000 \mathrm{~s}$, deposition time was selected based on the content of $\mathrm{Tl}$ in the sample. Pulse amplitude was $25 \mathrm{mV} \mathrm{s}^{-1}$, and the polarization rate $20 \mathrm{mV} \mathrm{s}^{-1}$. For total $\mathrm{Tl}$ determination the applied electrolyte contained $9.9 \mathrm{~mL}$ of distilled water and $100 \mu \mathrm{L}$ of conc. $\mathrm{HNO}_{3}$. To transform $\mathrm{Tl}$ compounds into free $\mathrm{Tl}^{+}$ions the sample was evaporated to dryness with $1 \mathrm{~mL}$ conc. $\mathrm{HNO}_{3}$. The content of TI(I) in the presence of Tl(III) DTPA was measured in an electrolyte consisting of $1 \mathrm{~mL}$ of 0 . $2 \mathrm{~mol} \mathrm{~L}^{-1}$ acetate buffer, $\mathrm{pH} 5.5,1 \mathrm{~mL}$ of $0.15 \mathrm{~mol} \mathrm{~L}^{-1}$ DTPA solution and $8 \mathrm{~mL}$ of DI water. For quantitative determinations the double standard addition method was used.

\section{Results and discussion}

Thallium (III) is unstable in a solution, and undergoes a rapid reduction to Tl(I). To prepare a Tl(III) standard solution it is necessary to stabilize the trivalent form by addition of complexing agents. The most popular are chlorides and DTPA. If the concentration of Tl(III) is relatively high (some $\left.10 \mathrm{mg} \mathrm{L}^{-1}\right), \mathrm{Tl}(\mathrm{Cl})_{4}{ }^{-}$is stable enough. In solutions with low concentrations (below $\mathrm{m} \mathrm{L}^{-1}$ level) the reduction of $\mathrm{Tl}(\mathrm{III})$ is noticed (25-30\%) [10]. In such cases the addition of DTPA is required [8], but even then the reduction occurs, although it is significantly limited (3-5\%) [10, 13]. Tl(III)DTPA complex is very stable, in diluted solutions and also in the presence of other ions. The stability of this complex is practically independent of $\mathrm{pH}$ (the optimal $\mathrm{pH}$ range is 6-8). In our studies this ligand was used to stabilize Tl(III) in solutions.

\section{Retention of $\mathrm{Tl}$ standards on pure alumina}

In view of the amphoteric character of alumina, it can be applied both as cation and anion exchanger, depending on the $\mathrm{pH}$ [21]. The preliminary study was done based on standard solutions. The solution containing $1.0 \mathrm{~mL}$ of $500 \mathrm{ng}$ of TI(I) or 550 ng of TI(III) (as Tl(III)DTPA) was loaded on the SPE column $\left(\mathrm{Al}_{2} \mathrm{O}_{3}\right)$. The effluent obtained in step 3 contained $8-11 \%(n=4)$ of added $\mathrm{Tl}(\mathrm{I})$ and the eluate obtained in step 4 contained only $0.1-0.2 \%(n=4)$ of added Tl(III). Both forms of $\mathrm{Tl}$ were retained on the sorbent.

Only Tl(I) ions can be determined by voltammetry, because only this species is accumulated on the electrode. Tl(III) bound in a complex compound is electrochemically inactive. The recovery of $\mathrm{Tl}$ introduced as Tl(III)DTPA was close to $0.2 \%(n=4)$ for the effluent obtained in step 3. Mineralization of the sample was applied to transform $\mathrm{Tl}$ compounds into free ions (the sample of effluent was evaporated to dryness with $1 \mathrm{~mL}$ conc. $\mathrm{HNO}_{3}$ ). For mineralized effluent, the recovery was 
Table 2 Recovery [\%] of Tl(I) and Tl(III) from samples with different excess of Tl(I) over Tl(III). The samples contained $20 \mathrm{ng}$ Tl(III) and an excess of $\mathrm{Tl}(\mathrm{I})$ of 5, 10, 50, 100 and 200 -fold in $10 \mathrm{~mL}$. The results are presented as a mean value $\pm \mathrm{SD}(n \geq 3)$

\begin{tabular}{|c|c|c|c|c|c|c|c|c|}
\hline \multirow[t]{2}{*}{ Step } & \multirow{2}{*}{$\begin{array}{l}\text { Eluted Tl } \\
\text { species }\end{array}$} & \multicolumn{7}{|c|}{$\mathrm{Tl}(\mathrm{I}): \mathrm{Tl}(\mathrm{III})$ (contribution to the total $\mathrm{Tl}$ amount) } \\
\hline & & $100 \%: 0 \%$ & $0 \%: 100 \%$ & $\begin{array}{l}83 \%: 17 \% \\
5: 1\end{array}$ & $\begin{array}{l}91 \%: 9 \% \\
10: 1\end{array}$ & $\begin{array}{l}98 \%: 2 \% \\
50: 1\end{array}$ & $\begin{array}{l}99 \%: 1 \% \\
100: 1\end{array}$ & $\begin{array}{l}99.9 \%: 0,1 \% \\
200: 1\end{array}$ \\
\hline 3 & $\mathrm{Tl}(\mathrm{I})$ & $96 \pm 2 \%$ & $2.0 \pm 0.6 \%$ & $81 \pm 2 \%$ & $86 \pm 2 \%$ & $96 \pm 2 \%$ & $90 \pm 1 \%$ & $41 \pm 0.2 \%$ \\
\hline $3 \mathrm{~A}$ & & $3.0 \pm 0.4 \%$ & $1.0 \pm 0.1 \%$ & $2.0 \pm 0.1 \%$ & $3.0 \pm 0.3 \%$ & $4.0 \pm 0.3 \%$ & $8 \pm 1 \%$ & $26 \pm 0.1 \%$ \\
\hline \multirow[t]{2}{*}{4} & $\mathrm{Tl}(\mathrm{III})$ & $<0,1 \%$ & $96 \pm 1 \%$ & $16 \pm 3 \%$ & $10 \pm 1 \%$ & $1.0 \pm 0.5 \%$ & $1.0 \pm 0.2 \%$ & $22 \pm 0.2 \%$ \\
\hline & Total T1 & $99 \pm 2 \%$ & $99 \pm 1 \%$ & $99 \pm 4 \%$ & $99 \pm 2 \%$ & $101 \pm 2 \%$ & $99 \pm 1 \%$ & $89 \pm 1 \%$ \\
\hline
\end{tabular}

slightly higher, close to $0.4 \%(n=4)$. The comparison of the results of ASV determination of $\mathrm{Tl}$ in effluent (step 3) prepared with and without the mineralization step, let to conclude that none of $\mathrm{Tl}$ forms left the column. Almost total retention of Tl(III) was observed.

Next, the composition of the eluent for thallium adsorbed as Tl(III)DTPA was optimized. According to the literature data, alumina is applied as a cation exchanger at $\mathrm{pH}$ about 8-9, and as an anion exchanger at $\mathrm{pH}$ 6-7. Usually to regenerate alumina sorbent strong alkaline solutions are used. Therefore, the solutions of $\mathrm{NaOH}(\mathrm{pH} 7.3 ; 8.4 ; 10.5$ and 11.5) were used to leach $\mathrm{Tl}$ species retained on the sorbent. However, the recovery study did not prove the theory, and the leaching efficiency did not exceed $0.4 \%$. Next, the solution of extremely low $\mathrm{pH}$ was checked as an eluate. In strongly acidic media the sorption capacity of alumina is low [21]. Solutions of $\mathrm{HNO}_{3}$ (pH 2.0 and 0) were checked. Only $60 \% \mathrm{HNO}_{3}$ allowed to leach $9.4-10.4 \%$ of added Tl $(n=4)$. Such low recovery can be explained with the fact that anion-exchange properties change gradually over fairly broad $\mathrm{pH}$ ranges. Additionally, the elution with concentrated nitric acid caused some destruction of the sorbent.

\section{Retention of TI on alumina modified with SDS}

The literature data $[16,19]$ indicated that alumina modified with a surfactant can be a good sorbent to retain the studied analyte. The column with the sorbent was prepared according to the scheme presented below (see Analytical Application section). A recovery study was carried out with $1.0 \mathrm{~mL}$ of standard solution containing $200 \mathrm{ng}$ of $\mathrm{Tl}(\mathrm{I})$, or $200 \mathrm{ng}$ of $\mathrm{Tl}$ (III) loaded on SPE columns - $\mathrm{Al}_{2} \mathrm{O}_{3}$-SDS. The recovery of $\mathrm{Tl}(\mathrm{I})$ in the column effluent collected in step 3 was about $71-77 \%(n=4)$. The introduction of step 3A to wash Tl(I) adsorbed in step 3 , increased the recovery of $\mathrm{Tl}(\mathrm{I})$ to $101-$ $105 \%$. First attempt to elute the retained Tl(III) (step 4) was by using EtOH but the leaching of Tl(III) was close to $0 \%$. Next, $1 \mathrm{~mL}$ of pure $\mathrm{ACN}$ and $1 \mathrm{~mL}$ of $1 \mathrm{~mol} \mathrm{~L}^{-1} \mathrm{HNO}_{3}$ were tested as eluents. The extractability of Tl(III) using ACN was very low, only $2-7 \%$ of added Tl(III) was recovered. Elution with $1 \mathrm{~mol} \mathrm{~L}^{-1} \mathrm{HNO}_{3}(\mathrm{pH} 0)$ was more efficient - the recovery for $\mathrm{Tl}(\mathrm{III})$ was up to $15 \%$. In $\mathrm{pH}<1$ the stability of Tl(III)DTPA was extremely low, due to competitive reactions - strong protonation of DTPA and acceleration of Tl(III) reduction to $\mathrm{Tl}(\mathrm{I})$. It causes the elution of $\mathrm{Tl}$ retained as complex. Therefore, $10 \mathrm{~mol} \mathrm{~L}^{-1}(40 \%)$ nitric acid was checked. The obtained results were satisfying, the recovery of $\mathrm{Tl}(\mathrm{I})$ and Tl(III) was close to $99 \%$ (Table 2). The final procedure consisted of four steps (Table 1) and in further study such scheme was applied.

The preparation of the SPE column was simple and inexpensive, as only one chemical modifier (SDS) is used. Additionally, the amount of sorbent packed into one column was only $500 \mathrm{mg}$ (considerably less than in Dadfarnia et al.

Table 3 Recoveries [\%] of $\mathrm{Tl}$ in the presence of various interfering ions: $\mathrm{Pb}(\mathrm{II}), \mathrm{Cd}(\mathrm{II})$ and $\mathrm{Zn}(\mathrm{II})$ The samples contained $\mathrm{Tl}(\mathrm{III})$ (10 no in $10 \mathrm{~mL}$, as Tl(III)DTPA), and 200, 500, and 700-fold molar excess of

$\mathrm{Pb}$ (II) and $\mathrm{Cd}(\mathrm{II})$ and 500, 700, and 2000-fold molar excess of $\mathrm{Zn}$ (II). The results are presented as a mean value $\pm \mathrm{SD}(n \geq 3)$

\begin{tabular}{|c|c|c|c|c|c|c|c|c|c|c|}
\hline \multirow[t]{2}{*}{ Step } & \multirow{2}{*}{$\begin{array}{l}\text { Eluted Tl } \\
\text { species }\end{array}$} & \multicolumn{3}{|l|}{$\mathrm{Pb}$} & \multicolumn{3}{|l|}{$\mathrm{Cd}$} & \multicolumn{3}{|l|}{$\mathrm{Zn}$} \\
\hline & & 200 & 500 & 700 & 200 & 500 & 700 & 500 & 700 & 2000 \\
\hline 3 & $\mathrm{Tl}(\mathrm{I})$ & $3.0 \pm 0.4 \%$ & $3.0 \pm 0.2 \%$ & $5 \pm 3 \%$ & $3 \pm 2 \%$ & $3 \pm 1 \%$ & $7 \pm 6 \%$ & $3.0 \pm 0.6 \%$ & $3 \pm 1 \%$ & $3 \pm 1 \%$ \\
\hline $3 \mathrm{~A}$ & & $1.0 \pm 0.4 \%$ & $1.0 \pm 0.2 \%$ & $2.0 \pm 0.4 \%$ & $0.6 \pm 0.1 \%$ & $0.2 \pm 0.1 \%$ & $1.0 \pm 0.4 \%$ & $0.6 \pm 0.4 \%$ & $0.6 \pm 0.1 \%$ & $0.6 \pm 0.1 \%$ \\
\hline \multirow[t]{2}{*}{4} & $\mathrm{Tl}(\mathrm{III})$ & $95 \pm 4 \%$ & $94 \pm 5 \%$ & $75 \pm 7 \%$ & $100 \pm 5 \%$ & $92 \pm 2 \%$ & $74 \pm 6 \%$ & $95 \pm 1 \%$ & $94 \pm 3 \%$ & $100 \pm 3 \%$ \\
\hline & Total thallium & $99 \pm 4 \%$ & $98 \pm 5 \%$ & $82 \pm 7 \%$ & $104 \pm 5 \%$ & $95 \pm 2 \%$ & $82 \pm 8 \%$ & $99 \pm 1 \%$ & $98 \pm 3 \%$ & $104 \pm 3 \%$ \\
\hline
\end{tabular}


Table 4 Recovery [\%] of thallium from water samples spiked with Tl(I) and Tl(III). The samples contained $40 \mathrm{ng} \mathrm{Tl}(\mathrm{III})$ and 10 or 50 -fold excess of $\mathrm{Tl}(\mathrm{I})$ in $10 \mathrm{~mL}$. The results are presented as a mean value $\pm \mathrm{SD}(n \geq 3)$

\begin{tabular}{llll}
\hline Step & Eluted Tl species & $\begin{array}{l}\text { Tl(I):Tl(III) } \\
91 \%: 9 \% \\
10: 1\end{array}$ & $\begin{array}{l}98 \%: 2 \% \\
50: 1\end{array}$ \\
\hline 3 & & $88 \pm 2 \%$ & $96 \pm 1 \%$ \\
$3 \mathrm{~A}$ & $\mathrm{Tl}(\mathrm{I})$ & $3.0 \pm 0.5 \%$ & $3.0 \pm 0.8 \%$ \\
4 & & $9.0 \pm 0.5 \%$ & $2 \pm 1 \%$ \\
& Tl(III) & $100 \pm 2 \%$ & $101 \pm 1 \%$ \\
\hline
\end{tabular}

*Contribution in the total $\mathrm{Tl}$ amount

[19]). SDS, which is an anionic surfactant, forms micelles and retains Tl(III)DTPA ${ }^{2-}$ by formation of van der Waals forces between the nonpolar part of SDS and DTPA [21]. This method of extraction seems to be an effective and simple method of separation of Tl(III)DTPA ${ }^{2-}$.

\section{Sample volume}

The study of sample volume is an important part of speciation analysis because preconcentration is necessary. Usually a sorbent which was modified by simple rinsing with reagents has low tolerance for large sample volumes. To recognize the breakthrough volume, samples containing $200 \mathrm{ng}$ of $\mathrm{Tl}(\mathrm{I})$ or
$\mathrm{Tl}(\mathrm{III})$ (as Tl(III)DTPA) in 5, 10, 50, 70 and $100 \mathrm{~mL}$ of solution were introduced to SPE columns $\left(\mathrm{Al}_{2} \mathrm{O}_{3}\right.$-SDS). The results of $\mathrm{Tl}$ determination in eluates obtained in all procedure steps indicated the following recovery of thallium species: $95 \pm 2 \%$ for $\mathrm{Tl}(\mathrm{I})$ and $95 \pm 4 \%$ for $\mathrm{Tl}(\mathrm{III})$ for $5.0 \mathrm{~mL}$ sample, $99 \pm 2 \%$ for Tl(I) and $99 \pm 1 \%$ for Tl(III) for $10.0 \mathrm{~mL}$ sample, $98 \pm 1 \%$ for $\mathrm{Tl}(\mathrm{I})$ and $98 \pm 3 \%$ for Tl(III) for $50 \mathrm{ml} \mathrm{sample,}$ $97 \pm 3 \%$ for $\mathrm{Tl}(\mathrm{I})$ and $89 \pm 3 \%$ for Tl(III) for $70 \mathrm{~mL}$ sample, $95 \pm 2 \%$ for $\mathrm{Tl}(\mathrm{I})$ and $86 \pm 2 \%$ for $\mathrm{Tl}(\mathrm{III})$ for $100 \mathrm{~mL}$ sample. It was found that even $50-55 \mathrm{~mL}$ of sample can be applied. The $10 \mathrm{~mL}$ volume was selected for further experiments, because it was the most convenient to collect the eluates in $10 \mathrm{~mL}$ vials.

\section{Application of a mixture of Tl(I) and Tl(III)}

The significant limitation in the speciation analysis of $\mathrm{Tl}$ is the large excesses of Tl(I) over Tl(III) in natural samples. During the following experiments various excesses of Tl(I) over Tl(III) were checked. The samples loaded on the SPE column contained Tl(III) (20 ng in $10 \mathrm{~mL}$ ), and $\mathrm{Tl}(\mathrm{I})$ in 5, 10, 50, 100 and 200-fold excess (Table 2).

The recoveries of both $\mathrm{Tl}(\mathrm{I})$ and $\mathrm{Tl}(\mathrm{III})$ are ca. $100 \%$ when the excess of $\mathrm{Tl}(\mathrm{I})$ is not higher than 200. When the excess was higher, total recovery decreased (to $89 \%$ ) and significant part of $\mathrm{Tl}$ was eluted in step 4 .

Table 5 Short comparison of methods of thallium speciation analysis using SPE for thallium species separation

\begin{tabular}{|c|c|c|c|c|c|}
\hline Sorbent 1 & $\begin{array}{l}\text { LOD } \\
{\left[\mathrm{ng} \mathrm{mL}^{-1}\right]}\end{array}$ & Effects of $\mathrm{pH}$ & Interfering ions (tolerable excess) & $\begin{array}{l}\text { General } \\
\text { advantages/disadvantages }\end{array}$ & Ref. \\
\hline $\begin{array}{l}\text { SGX C18 modified } \\
\text { with DDTC }\end{array}$ & $\begin{array}{l}0.05 \mathrm{Tl}(\mathrm{I}) \\
0.21 \mathrm{Tl}(\mathrm{III})\end{array}$ & not studied & $\begin{array}{l}1000-\mathrm{Cu}(\mathrm{II}), 700-\mathrm{Zn}(\mathrm{II}) \text { and } \mathrm{Sn}(\mathrm{II}) \\
500-\mathrm{Pb}(\mathrm{II}) \text { and } 100-\mathrm{Cd}(\mathrm{II})\end{array}$ & $\begin{array}{l}\text { direct speciation of } \mathrm{Tl}(\mathrm{I}) \text { and } \mathrm{Tl}(\mathrm{III}) / \\
\text { low tolerance for } \mathrm{Tl}(\mathrm{I}) \text { excess }\end{array}$ & 15 \\
\hline nano- $\mathrm{Al}_{2} \mathrm{O}_{3}$ & $800 \mathrm{Tl}(\mathrm{III})$ & $\begin{array}{l}\text { best sorption at } \\
\text { pH } 3.0-4.5\end{array}$ & $\begin{array}{c}5-\mathrm{Ca}(\mathrm{II}) \text { and } \mathrm{Mg}(\mathrm{II}), 10-\mathrm{Zn}(\mathrm{II}), 1,5 \\
\mathrm{~Pb}(\mathrm{II}), 3,0-\mathrm{Ga}(\mathrm{III}), 9,5-\mathrm{Sb}(\mathrm{III}), 10 \\
-\mathrm{Ge}(\mathrm{IV}), \mathrm{Se}(\mathrm{IV}), 7,5-\mathrm{Re}(\mathrm{IV}), 2 \\
\mathrm{Li}(\mathrm{I}), 5 \mathrm{~V}(\mathrm{~V}), 6-\mathrm{Sr}(\mathrm{II}), 7-\mathrm{Mo}(\mathrm{VI}), \\
10-\mathrm{As}(\mathrm{III}), 70-\mathrm{NO}_{3}{ }^{-} \text {and } \mathrm{SO}_{4}{ }^{-}, \\
\\
60-\mathrm{CO}_{3}{ }^{2-}, 10-\mathrm{PO}_{4}{ }^{3-}, 100-\mathrm{Cl}^{-}\end{array}$ & $\begin{array}{l}\text { high sorption capacity and rapid } \\
\text { separation/breakthrough volume } \\
\text { lower than } 25 \mathrm{~mL} \text { and high LOD }\end{array}$ & 16 \\
\hline $\mathrm{Al}_{2} \mathrm{O}_{3}$-oxine & $2.5 \mathrm{Tl}(\mathrm{I})$ & $\begin{array}{l}\mathrm{Tl}(\mathrm{I}) \text { deposition at } \\
\mathrm{pH} 2.5 \text { to } 11\end{array}$ & $\begin{array}{c}1000-\mathrm{Mg}(\mathrm{II}), \mathrm{Na}(\mathrm{I}) \mathrm{K}(\mathrm{I})^{\prime} \mathrm{Zn}(\mathrm{II}) \\
\mathrm{Pb}(\mathrm{II}), \mathrm{Cu}(\mathrm{II}), \mathrm{Co}(\mathrm{II}), \mathrm{Ni}(\mathrm{II}), \mathrm{Cs}(\mathrm{I}) \\
\mathrm{I}, \mathrm{Cl}, \mathrm{SO}_{3}{ }^{2-} ; 750-\mathrm{Cd}(\mathrm{II}), \mathrm{Ag}(\mathrm{I}) \\
500-\mathrm{Ca}(\mathrm{II}), \mathrm{Fe}(\mathrm{III}), \mathrm{CO}_{3}{ }^{2-}\end{array}$ & $\begin{array}{l}\text { simple preparation of microcolumn, } \\
\text { high reproducibility/long time of } \\
\text { sample preparation before loading }\end{array}$ & 19 \\
\hline modified silica & $0.72 \mathrm{Tl}(\mathrm{III})$ & not studied & $\begin{array}{l}250-\mathrm{Cl}^{-} \text {and } 100-\mathrm{NO}_{3}{ }^{-}, \mathrm{SO}_{4}{ }^{2-} \\
\mathrm{Ca}(\mathrm{II}), \mathrm{Mg}(\mathrm{II}), \mathrm{K}(\mathrm{I}), \mathrm{Al}(\mathrm{III}) \text { and } \\
\mathrm{Fe}(\mathrm{III})\end{array}$ & $\begin{array}{l}\text { use of AAS and determination of } \\
\mathrm{Tl}(\mathrm{III}) / \text { indirect speciation analysis of } \\
\mathrm{Tl}\end{array}$ & 20 \\
\hline Chromosorb 105 & $0.034 \mathrm{Tl}(\mathrm{III})$ & not studied & $\begin{array}{l}500000-\mathrm{Ca}(\mathrm{II}) \text { and } \mathrm{Zn}(\mathrm{II}), 250000- \\
\mathrm{CO}_{3}{ }^{2-}, \mathrm{PO}_{4}{ }^{3-}, 5000000-\mathrm{Fe}(\mathrm{II}) \\
\mathrm{Fe}(\mathrm{III}), \mathrm{Al}(\mathrm{III}), \mathrm{Cl}^{-}, 2500000 \\
\mathrm{Na}(\mathrm{I}) \text { and } \mathrm{K}(\mathrm{I}), 2000000 \mathrm{Mg}(\mathrm{II}), \\
1000000 \mathrm{SO}_{4}{ }^{2-} \text { and } 25000 \mathrm{Ni}(\mathrm{II}) \\
\text { and } \mathrm{Cu}(\mathrm{II})\end{array}$ & $\begin{array}{l}\text { simple, reliable way of } \mathrm{Tl}(\mathrm{III}) \\
\text { preconcentration and low } \mathrm{LOD} / \\
\text { suitable only for AAS determination } \\
\text { and important interferences from } \mathrm{Cr} \\
\text { and Co cations }\end{array}$ & 24 \\
\hline $\mathrm{Al}_{2} \mathrm{O}_{3}-\mathrm{SDS}$ & $\begin{array}{l}0.025 \mathrm{Tl}(\mathrm{I}) \\
0.16 \mathrm{Tl}(\mathrm{III})\end{array}$ & sample $\mathrm{pH}$ 5-6 & $500-\mathrm{Pb}$ and $\mathrm{Cd}, 2000-\mathrm{Zn}$ & $\begin{array}{l}\text { direct speciation of } \mathrm{Tl}(\mathrm{I}) \text { and } \mathrm{Tl}(\mathrm{III}) \\
\text { self-made column and high sorption } \\
\text { capacity/use of conc. acid as eluent }\end{array}$ & this work \\
\hline
\end{tabular}

Abbreviations: SGX C18: silica gel with octadecyl-groups, DDTC: diethyldithiocarbamate, SDS: sodium dodecyl sulfate 
Additionally, the capacity of the sorbent was evaluated. The samples applied to the SPE column contained Tl(III) $(200,400,800$ and $1000 \mathrm{ng}$ in $10 \mathrm{~mL})$. The recovery of $\mathrm{Tl}$ (III) was $0.1-0.2 \%$ in step 3 and $<0.1 \%$ in step $3 \mathrm{~A}$, indicating a very high capacity of the sorbent.

\section{Interferences}

Thallium species are released into the environment mainly as a result of exploitation of sulfide ores [2]. Such ores contain small fractions of $\mathrm{Tl}$ and their main components include the ions of $\mathrm{Zn}, \mathrm{Cd}$ or $\mathrm{Pb}$ [22]. These also react with DTPA and thus can compete with $\mathrm{Tl}$ in the adsorption process. Considering the above, interferences from various excesses of those metals were checked. The samples applied to the SPE column contained $\mathrm{Tl}$ (III) $(10 \mathrm{ng}$ in $10 \mathrm{~mL}$, as Tl(III)DTPA) and 200, 500, and 700-fold molar excess of $\mathrm{Pb}$ (II) and $\mathrm{Cd}(\mathrm{II})$ and 500, 700, 2000-fold molar excess of $\mathrm{Zn}$ (II) (as nitrates) (Table 3). No interferences were caused by 500 -fold excess of $\mathrm{Pb}$ and $\mathrm{Cd}$, and 2000-fold excess of $\mathrm{Zn}$ (recovery ca. $100 \%$ ). Negative impact was only observed for 700 -fold excess of $\mathrm{Pb}$ and $\mathrm{Cd}$.

\section{Analytical application}

Wastewater samples were taken from a water outlet located in one of the most polluted areas in Poland (Upper Silesia). The wastes containing tailing minerals rich in $\mathrm{Tl}$ are deposited there in large ponds [23]. Samples of wastewater were taken in $1 \mathrm{~L}$ glass bottle, immediately acidified to $\mathrm{pH} 2$ with $\mathrm{HNO}_{3}$ and stored until analysis. The original sample was slightly spiked with $\mathrm{Tl}(\mathrm{I})$ and $\mathrm{Tl}(\mathrm{III})$ standard solutions. The samples applied to the SPE column contained $40 \mathrm{ng} \mathrm{Tl}(\mathrm{III})$ and 10- or 50 -fold excess of Tl(I) in $10 \mathrm{~mL}$ (Table 4). The recoveries of both $\mathrm{Tl}$ species were close to $100 \%$. The reproducibility of the procedure was about $2 \%$ for $\mathrm{Tl}(\mathrm{I})$ and $1 \%$ for $\mathrm{Tl}(\mathrm{III})$. Step $3 \mathrm{~A}$ is necessary because of $3 \%$ co-sorption of $\mathrm{Tl}(\mathrm{I})$ in step 3 , and skipping step $3 \mathrm{~A}$ can lead to wrong conclusions about $\mathrm{Tl}$ speciation.

The limit of detection (LOD) was calculated as a mean value increased by 3 -times the standard deviation of $\mathrm{Tl}$ concentration in the blank sample $(10 \mathrm{~mL})($ mean $+x 3 \mathrm{SD}, n=4)$ and it amounted to $0.025 \mathrm{ng} \mathrm{mL}^{-1}$ for Tl(I) and $0.16 \mathrm{ng} \mathrm{mL}^{-1}$ for Tl(III). The limit of quantification (LOQ) was calculated as a mean value increased by 10-times the standard deviation of $\mathrm{Tl}$ concentration in the blank sample $(x$ mean $+10 \mathrm{SD}, n=4)$ and it amounted to $0.067 \mathrm{ng} \mathrm{mL}^{-1}$ for $\mathrm{Tl}(\mathrm{I})$ and $0.19 \mathrm{ng} \mathrm{mL}^{-1}$ for $\mathrm{Tl}(\mathrm{III})$.

A detailed comparison of this method to other methods of $\mathrm{Tl}(\mathrm{III})$ separation is presented in Table 5. The developed procedure allows determining $\mathrm{Tl}(\mathrm{III})$ below $\mu \mathrm{g} \mathrm{L}^{-1}$ level in wastewater matrix. The LOD is lower than in methods described in the literature $[15,16,19,20]$. The procedure is characterized by $50 \mathrm{~mL}$ breakthrough volume, which is equal to values reported for procedures based on retention on SGX C18 modified with a cationic surfactant [20] and slightly lower than for procedure based on Chromosorb105 [24]. It is also highly tolerant to the excess of Tl(I) over Tl(III). The tolerance is much higher than in methods mentioned above. The efficiency of retention and preconcentration is much less affected by the presence of $\mathrm{Zn}$ than it was mentioned in references $[15$, 16], and the retention is comparably affected by $\mathrm{Pb}$. The great advantage of the procedure based on sorption on $\mathrm{Al}_{2} \mathrm{O}_{3}$ - $\mathrm{SDS}$ is the possibility of direct determination of $\mathrm{Tl}(\mathrm{III})$ and $\mathrm{Tl}(\mathrm{I})$, without mathematical calculation of the concentration of one of $\mathrm{Tl}$ forms $[15,24]$. Additionally, the preparation of a selfmade sorbent significantly reduces the cost of analysis.

\section{Concluding remarks}

We developed a new method of direct speciation analysis of thallium, based on solid phase extraction using $\mathrm{Al}_{2} \mathrm{O}_{3}$-SDS as a sorbent. Only $\mathrm{Tl}(\mathrm{III})$ was retained. The procedure is highly tolerant to great excesses of $\mathrm{Tl}(\mathrm{I})$ over $\mathrm{Tl}(\mathrm{III})$, and to high content of interfering metals, such as $\mathrm{Pb}, \mathrm{Cd}$, and $\mathrm{Zn}$. The great advantage of this method is the high capacity of the sorbent (up to $1 \mu \mathrm{g}$ of $\mathrm{Tl}$ can be pre-concentrated on a single column). The method was successfully applied in case study analyzing wastewater samples. Low LOD, simple composition of the eluates and nearly no interfering ions enable its offline coupling with any of the elemental methods of detection, and make this method competitive to other methods previously described in the literature.

Acknowledgments The project was supported by the Polish Grant 120000-501/86-DSM-107 500 and National Science Centre (NCN) Poland Grant DEC-2011/01/B/NZ8/00052. Dr. Ospina-Alvarez gratefully acknowledges support by a post-doctoral grant from the AXA Research Fund (Paris, France).

Open Access This article is distributed under the terms of the Creative Commons Attribution 4.0 International License (http:// creativecommons.org/licenses/by/4.0/), which permits unrestricted use, distribution, and reproduction in any medium, provided you give appropriate credit to the original author(s) and the source, provide a link to the Creative Commons license, and indicate if changes were made.

\section{References}

1. Lin TS, Nriagu JO (1999) Thallium speciation in river waters with chelex-100 resin. Anal Chim Acta 395:301

2. Ospina-Alvarez N, Burakiewicz P, Sadowska M, KrasnodębskaOstrega B (2015) Tl(I) and Tl(III) presence in suspended particulate matter: speciation analysis of thallium in wastewater. Environ Chem 12:374

3. Krasnodebska-Ostrega B, Sadowska M, Ostrowska S (2012) Thallium speciation in plant tissues-T1(III) found in Sinapis alba 
L. grown in soil polluted with tailing sediment containing thallium minerals. Talanta 93:326

4. Schedlbauer OF, Heumann KG (1999) Development of an isotope dilution mass spectrometric method for dimethylthallium speciation and first evidence of its existence in the Ocean. Anal Chem 71(24): $5459-5464$

5. Lan $\mathrm{CH}$, Lin TS (2005) Acute toxicity of trivalent thallium compounds to Daphnia magna. Ecotoxicol Environ Saf 61:432

6. Pourahmad J, Eskandari MR, Daraei B (2010) A comparison of hepatocyte cytotoxic mechanisms for thallium (I) and thallium (III). Environ Toxicol 25:456

7. Łukaszewski Z, Karbowska B, Zembrzuski W (2003) Determination of mobile thallium in soil by flow injection differential pulse anodic stripping voltammetry. Electroanalysis 15(5-6):480

8. Karlsson U, Düker A, Karlsson S (2006) Separation and quantification of $\mathrm{Tl}(\mathrm{I})$ and $\mathrm{Tl}(\mathrm{III})$ in fresh water samples. J Environ Sci Health, Part A: Tox Hazard Subst Environ Eng 41:1157

9. Sekine T (1965) Solvent extraction study of trivalent actinide and lanthanide complexes in aqueous solution. Acta Chem Scand 19:1476

10. Krasnodębska-Ostręga B, Pałdyna J, Wawrzyńska M, Stryjewska E (2011) Indirect anodic stripping voltammetric determination of $\mathrm{Tl}(\mathrm{I})$ and $\mathrm{Tl}(\mathrm{III})$ in the Baltic sea water samples enriched in thallium species. Electroanalysis 23:605

11. Nowicka A, Krasnodębska-Ostręga B, Wrzosek B, Jastrzębska M, Sadowska M, Maćkiewicz M, Stojek Z (2014) Detection of oxidative damage of synthetic oligonucleotides caused by Tl(III) complexes. Electroanalysis 26:340

12. Scheckel K, Lombi E, Rock S, McLaughlin M (2004) In vivo synchrotron analysis of thallium in Iberis Intermedia. Environ Sci Technol 38(19):5095

13. Nolan A, Schaumlöffel D, Lombi E, Ouerdane L, Łobiński R, McLaughlin M (2004) Determination of Tl(I) and Tl(III) by ICICP MS and application to $\mathrm{Tl}$ speciation analysis in the $\mathrm{Tl}$ hyperaccumulator plant Iberis Intermedia. J Anal At Spectrom 19:757

14. Chu YL, Wang RY, Jiang SJ (2012) Speciation analysis of thallium by reversed-phase liquid chromatography - inductively coupled plasma mass spectrometry. J Chin Chem Soc 59:219
15. Krasnodębska-Ostrega B, Sadowska M, Piotrowska K, Wojda M (2013) Thallium (III) determination in the Baltic sea water samples by ICP MS after preconcentration on SGX C18 modified with DDTC. Talanta 112:73

16. Zhang L, Huang T, Liu X, Zhang M, Li K (2011) Selective solidphase extraction of trace thallium with nano- $\mathrm{Al}_{2} \mathrm{O}_{3}$ from environmental samples. J Anal Chem 66(4):368

17. Horiguchi R, Nukatsuka I, Shimizu Y, Sekikawa S, Ohzeki K (2002) Determination of thallium in water by electrothermal AAS with the direct injection of a cellulose nitrate resin suspension used for solid-phase extraction. Bunseki Kagaku 51:675

18. Mohammadi SZ (2012) Flame atomic absorption spectrometric determination of trace amounts of zinc and thallium in different matrixes after solid phase extraction on modified multiwalled carbon nanotubes. Am J Anal Chem 3:371

19. Dadfarnia S, Assadollahi T, Haji Shabani AM (2007) Speciation and determination of thallium by on line microcolumn separation/ preconcentration by flow injection-flame atomic absorption spectrometry using immobilized oxine as a sorbent. J Hazard Mater 148:446

20. Urbankova K, Sommer L (2008) The microdetermination of thallium by ICP-AES after previous preconcentration on modified silica. Comparison with integrated-platform graphite atomic absorption spectrometry. Microchim Acta 162:127-132

21. Laurent C, Billiet HAH, de Galan L (1983) On the use the alumina in HPLC with aqueous mobile phase at extreme $\mathrm{pH}$. Chromatographia 17(5):253

22. Cabała J, Teper L (2007) Metalliferous constituents of rhizosphere soils contaminated by $\mathrm{Zn}-\mathrm{Pb}$ mining in southern Poland. Water Air Soil Pollut 178:351

23. Krasnodębska-Ostręga B, Dmowski K, Stryjewska E, Golimowski J (2005) Determination of thallium and other elements (as, $\mathrm{Cd}, \mathrm{Cu}, \mathrm{Mn}, \mathrm{Pb}, \mathrm{Se}, \mathrm{Sb}$, and $\mathrm{Zn}$ ) in water and sediment samples from the vicinity of the zinc-lead smelter in Poland. J Soils Sediments 5(2):71

24. Karatepe A, Soylak M, Elci L (2011) Selective pre-concentration of thallium species as chloro and iodo complexes on chromosorb 105 resin prior to electrothermal atomic absorption spectrometry. Talanta 85:1974 